\title{
Adaptation actions for integrated climate risk management into urban planning: a new framework from urban typologies to build resilience capacity in Santos (SP)
}

Andrea Ferraz Young*

\begin{abstract}
Introduction: Many coastal cities have recently recognized the need to adapt to climate change, given the increased frequency of disasters cause by severe weather events. Based on concepts about vulnerability and resilience, we identify the limitations and opportunities of synergy between different areas of municipal action.

Case description: This paper explores the emerging linkages between city planning process and environmental disasters prevention in Santos (Brazil). To help visualize this process, we explore the emerging linkages between lowlying lands affected by sea level rise (SLR) and weather related hazards, such as floods and landslides, and we proposed some urban typologies to assist the identification of risk areas that reflect the importance of the urban design as a part of a broader set of decisions.

Discussion and Evaluation: The government agencies and political coalitions are reconnecting in the city planning process by working to change the social and political institutions to make local areas at risk safest places. A framework of decision making process through urban typologies addressed to the political conditions and some institutional arrangements occurred in order to promote disaster risk management. In this context, important programs were addressed to residential areas using legal/formal mechanisms to provide a significant reduction of disasters.

Conclusion: In order to meet long-term global target for disasters reduction, it is important to realize that the choices are not permanent solutions because it is a continuous process that can be updated based on realistic solutions, but the experiences in Santos represent pioneering efforts in Brazil that define urban rules and adaptive policies with substantial responsibilities for local government and society, demanding ongoing tracking as they evolve and become mature.
\end{abstract}

Keywords: Climate change, Sea level rise, Floods, Landslides, Resilience

\section{Background}

Resilience is a property of social-ecological systems interactions (Boonstra 2016) and is defined as the capability of a system to maintain its functions and structure in the face of endogenous and exogenous disturbances (Allenby and Fink 2005). Given the high degree of uncertainty and complexity of the system, it is essential to create a clear

\footnotetext{
*Correspondence: andfyoung@hotmail.com State University of Campinas, Cidade Universitária Zeferino Vaz, Campinas CEP 13083-970, Brazil
}

vision of city planning and environment connections at the beginning of the urban planning process in order to highlight some of the challenges to integrate these fields (Corburn 2009).

Urbanization processes, particularly those governing land use, housing, transportation, public services, and environment conservation are increasingly understood as powerful determinants of population vulnerability to climate change (IPCC 2014a).

Resilient city planning will require new issue and problem framings, analytical procedures and deliberative 
public processes that together can generate norms and practice for safest places. Physical changes without accompanying social, political and institutional engagement will ultimately fail to prevent disasters and move urban decisions toward planning less resilient (Pelling 2011).

Within this perspective, the city planning must be viewed as an integrated process with governance, where both the substantive content of what contributes to human well-being, and the decision-making processes that shape the distribution of these attributes across spaces and social groups, are improved (Dodman et al. 2013).

Frequently, it requires the ability to take advantage of different initiatives which involves multiple scales (Allenby and Fink 2005) and is crucial for governance and political decisions (Cosens 2013). Consequently, the development of societies depends largely on understanding and managing the growth of cities (historical and political development, spatial networks, and geographical scales) (Swyngedouw and Heynen 2003).

This paper explores the potential impacts of sealevel-rise (SLR) in Santos located on the coast of Southeast Brazil, $65 \mathrm{~km}$ far from São Paulo (IBGE 2010). Remote sensing and geographic information systems (GIS) were used to develop and synthesize scenarios through digital elevation data, land cover and local characteristics.

In the second half of the twentieth century, technological change and innovations were essential sources of structural change, industrial development, and economic growth, giving rise to an integrated petrochemical pole set in Cubatão, covering an area of $160 \mathrm{~km}^{2}$ in Serra do Mar slopes and in estuarine lands (Gasparro et al. 2008).

With the establishment of the Presidente Bernard's refinery, Santos harbor became an oil terminal and the neighboring area turned into an industrial center (Gasparro et al. 2008). The development and the expansion of industrial activities contributed extensively to economic growth and increased job supply in Santos (Sampaio and Ferreira 2008), establishing solid bridges with commerce and real estate market (Santos 2014).

Over the past two decades, the population growth has slowed down and Santos has not increased significantly, particularly influenced by urban dynamics with a complex system of commuting flows-intra metropolitan (Santos > Baixada Santista > Santos) and inter metropoli$\tan$ (Santos > São Paulo > Santos) (Cunha et al. 2006).

Santos fulfilled its role as a management pole with efficiency due to high human resource levels (i.e. education and income) and public institutions that were relatively well functioning. Santos attracted a higher income population that could acquire high standard residences or pay for high cost of land, infrastructure and services, while a lower income population stablished in surrounding areas or neighboring cities, where land was cheaper and predominated illegal housing ${ }^{1}$ with inadequate building structures (Miller et al. 2012).

In 2013, Santos was experiencing rapid economic growth driven by development of the pre salt offshore basins, industrial and port related activities, responsible for 7th best position of state and the 17th place in the country of the Brazilian Gross Domestic Product (GDP) (Master Plan 2013).

The urban areas in Santos are highly complex with interdependent systems (i.e. harbor, international trade, tourism industry). A failing caused by an extreme event (e.g. storm surge with flooding) in these systems can result in cascading impacts that can disrupt, for example, the availability of electricity, transport and communications (Miller et al. 2012).

Changes in many extreme weather and climate events have been observed since 1950 and precipitation patterns are projected to change in the future, possibly resulting in coastal flooding (medium confidence) from storm surge and high tide (caused by sea level rise) (IPCC 2014b).

Cities face a chronic stresses or acute impacts, therefore special focus should be on the development of regulations and incentives to the interactions of concepts on climate change, city adaptation and resilience, through the perspective of transition for urban resilience, which enable cities change and build capacity of innovation in face of uncertainty (Ernstson et al. 2010).

This paper explores some questions highlighting how political actions and public decisions can improve the resilience of people and places in Santos (SP). What are the connections among city planning processes, climate change and resilience? How political decisions could connect planning and governance with special focus on adaptation and resilience?

\section{Objective}

The aim is to present a framework that describes the decision making process through urban typologies addressed to the political conditions and some institutional arrangements occurred in Santos (2005-2015) in order to promote disaster risk management. To achieve this objective we analyzed how the government agencies and political coalitions are reconnecting in the city planning process by working to change the social and political institutions to make local areas at risk safest places.

\footnotetext{
${ }^{1}$ It is important to highlight that $20 \%$ of city population was living in slums according to IBGE (2010).
} 


\section{Methods}

\section{Case study}

Santos is located in Baixada Santista Metropolitan Area (BSMA), $65 \mathrm{~km}$ from São Paulo Metropolitan Area, the largest metropolitan area in Brazil, with 21,090,791 habitants. The BSMA comprises nine municipalities (i.e. Santos, São Vicente, Cubatão, Guarujá, Praia Grande, Mongaguá, Itanhaém, Peruíbe, and Bertioga), with a population of 1,797,500 people (IBGE 2015).

Santos is separated into two distinct areas: an area located on an island (with $39.4 \mathrm{~km}^{2}$ ) where $99 \%$ of population ( 430,000 hab) is largely urban (density of 10,636.7 $\mathrm{hab} / \mathrm{km}^{2}$ ), and a continental area that is considered rural (Miller et al. 2012). The population of city is 433,966 inhabitants with a high concentration of people $\sim 1494.26$ $\mathrm{hab} / \mathrm{km}^{2}$, considering the whole territory. The population grew by $0.3 \%$ from 2000 to 2010 , due mainly to the difference between births and deaths, in spite of an outflow due to migration $(-3.22$ per thousand inhabitants during the period or -1.349 per year) (IBGE 2010).

The urban island set on the Atlantic coastal plain (average height $2 \mathrm{~m}$ above sea level) in Southeast Brazil centered near $23^{\circ} 57^{\prime} 39^{\prime \prime} \mathrm{S}, 46^{\circ} 20^{\prime} 01^{\prime \prime} \mathrm{W}$, a low-lying region within the Atlantic Mountain Chain. It occupies $280.9 \mathrm{~km}^{2}$ and is surrounded by hills that vary from 650 to $1200 \mathrm{~m}$ in height (above sea level) and by water at an elevation slightly above sea level. The area surrounding Santos is characterized by its rich biodiversity, encroaching on the remaining portions of the Atlantic forest biome (known as Mata Atlântica) and its extensive areas of mangrove, with associated fauna and flora (Master Plan 2013).

Geologically, Santos features a combination of granite, clay, and sands, particularly important because these soils can become unstable during the rainy season when the soils can become saturated, exposed and susceptible to landslides. Six main rivers discharge in the Santos estuary, classified as a sub-tropical mangrove system: Piacaguera, Boturoca, Cubatão, Mogi, Quilombo and Jurubatuba (Mateus et al. 2008).

According to SEADE (2013-2015), Santos was experiencing rapid economic growth driven by development of the pre salt offshore basins, industrial and port related activities, responsible for 7 th best position of state and the 17th place in the country of the Brazilian gross domestic product (GDP). Santos had a significant base to the employment (180.4 thousand employees), with a GDP about $\$ 5,396,603.08$, a GDP per capita around $\$ 12,791.31$ and a per capita income of about $\$ 382.33$. About $9.31 \%$ of households present income per capita up to $1 / 2$ minimum wage.

Its largest sector, services, represented $\sim 60 \%$ of the economy, and since 1990, Santos has seen the largest growth in its information services and business, mainly through the logistics and transport of the harbor with handling capacity of 97 million tons/year. The share of Port of Santos in national foreign trade increased with a surplus of US \$ 3.5 billion in 2011, the result of exports of US \$ 5.218 billion and imports of US \$ 1.699 billion (Master Plan 2013). From January of last year, the port operator (CODESP) reported that the total investments at the facility amounted to USD 8 million, and more USD 17 million in entrance and interior channels to allow movement to anchoring areas (Companhia Docas do Estado de São Paulo 2015).

In 2011, the labor market in the city of Santos grew $8.6 \%$, and was more robust than the state of São Paulo (4.1\%) and the total of country (4.4\%) (Master Plan 2013). However, according to SEADE (2013-2015), the unemployment rate in Santos jumped 8.9 \% in September 2014 to $12.2 \%$ in March 2015, greater than São Paulo Metropolitan Area, which was $11.4 \%$ in the same period. Current unemployment numbers reflect the crisis in the Brazilian economy (included pre salt and fossil fuel price slump) that has considerably negative impacts on domestic consumption, industrial production and the labor market. When focusing specifically on the labor market, it is expected a significant increase in unemployment, a reduction of medium wages, a deteriorating social protection, and a worsening of working conditions.

\section{Climate conditions and weather}

The annual temperature in Santos is about $21.9^{\circ} \mathrm{C}$ with a $5{ }^{\circ} \mathrm{C}$ difference between the summer and winter seasons caused mainly by its proximity to the ocean and their influences at the atmospheric circulation patterns. On average, the city of Santos receives about $2500 \mathrm{~mm}$ of total annual rainfall with $75 \%$ of the total rainfall occurring during the months from October to April, and an average monthly total of $317 \mathrm{~mm}$ (Miller et al. 2012). Different factors influence the upper-air circulation on the different timescales as well as the Tropical Atlantic sea surface temperature variability and its relation to El Niño-Southern Oscillation (Wang et al. 2004).

In national terms, Brazil experiences significant changes in rainfall during El Niño events, but a conjunction of phenomena affects the weather and extreme events including the South Atlantic Convergence Zone (SACZ) (Liebmann and Allured 2005; Carvalho et al. 2002, 2004), the Intertropical Convergence Zone (ITCZ) (Liu and Zipser 2005), and the South American Low Level Jet (SALLJ) (Boers et al. 2014a; Marengo et al. 2004), controlled by thermal gradients and topography, the main mechanisms of rainfall distribution in the continent (Amador 2008). The main sources for the convection variability in South America are African easterly 
waves, upper-level cyclonic vortices in northeast of Brazil, the South Atlantic convergence zone (SACZ), and the penetration of frontal systems into the subtropics and Tropics (Siqueira and Machado 2003).

To be more specific and maybe schematic, ENSO can affect the inter-annual variability (about $70 \%$ increase in rainfall above normal conditions) while SACZ and SALLJ can affect intra-seasonal variability (Boers et al. 2013, 2014b). A combination of factors related to the sea surface temperature (SST) in the Pacific and Atlantic oceans can affect the dynamic of these two important meteorological systems (Chiang and Vimont 2004; Nobre et al. 2006). For example, when El Niño is occurring the sea surface temperature in the Pacific becomes warmer than normal and the strength of winds reduce. La Niña is the opposite, when the sea surface temperatures become colder than normal and the strength of the wind increases (Boers et al. 2013, 2014b).

It is important to realize the frontal systems often interact with tropical convection over South America throughout the year and largely contributes to the convection variability in the Tropics during El Niño episodes, when the occurrence of intense blocking episodes of cold fronts over southeast of South America hinders the northward advance of cold fronts. These blocking episodes are characterized by an intensification of the Hadley circulation that propitiates a high transport of humidity and consequently a stronger subtropical jet stream than normal (Siqueira and Machado 2003).

Climate anomalies are not exactly new in Brazil; however the variability and frequency of storms, and cyclones over the past 30 years has concerned the specialists (Nobre et al. 2012; Marengo et al. 2013a, b, 2014; Espinoza et al. 2014). The period of rain are becoming more irregular, with intense rainfall events concentrated in a short period separated by warm dry periods (IPCC 2014b).

The heavy rain around Santos during an El Niño event is contrasted by La Niña events, when Santos tends to receive lower amount of rainfall than normal conditions. Basically, the region is affected by frontal, convective and orographic systems. The rains caused by frontal system are resultant of the meeting of a cold mass (and dry) with other hot (and humid), typical of the mid-latitudes, like the winter in Southern Brazil that go from the south (Argentina) and dissipate in the way (Nobre 2011; INPE 2016).

Convective rains, also called summer rains, are caused by intense evaporation of wet and hot surfaces such as forests (i.e. Atlantic Forest), urban areas and tropical oceans. Orographic rain or relief rains occur when warm moist winds rise and cool off by the meeting of a mountain barrier (i.e. Serra do Mar) facing the sea (Nobre 2011;
INPE 2016). In Santos, there is large variability in yearto-year monthly precipitation for the period of record from 1940 to 2012 which suggest an average monthly total of $317 \mathrm{~mm}$ with a standard deviation of $\pm 125 \mathrm{~mm}$ (Miller et al. 2012).

\section{Urban context}

City planning practice is about the processes that promote urban interventions to shape urban spaces, particularly those processes governing the territory such as land use, housing, transportation, job opportunities, social services, opportunities for commerce and business (Corburn 2009). Therefore, as considered in this paper, the city planning has some formal rules that define the content and direction of urban expansion.

Within this perspective, we could consider that the decisions have a significant influence over the outcomes of planning processes, such as whether they respond or not to claims of environmental destruction and lack of preventing disaster.

Accordingly, two central questions are equally important: what explains the distribution of environmental disasters and what drives current and changing patterns of urban spaces in terms of urban resilience and prevention across population groups? The current urban development model has proven to fail in granting urban safety (UNFPA 2015), actually, this pattern fosters financial profit to the benefit of a financial system at the expense of the majority of the population (Harvey 2014).

Urban resilience focuses on changing the social economic determinants of urban safety including the idea of resistance by mitigation of environmental stress; early warning and disaster prevention; educational tools and technical support; working conditions; access to public services (housing, transportation, health); legal and institutional support (Allenby and Fink 2005).

Studying the city planning of Santos is important because, surprisingly, the city is one of the most involved in prevention measures in Brazil (Miller et al. 2012), despite all the common problems of Brazilian cities. The case study is structured around three environmental threats: sea level rise, heavy rainfall and storm surge, and related hazards such as flooding, and landslides.

Each threat is considered within the city planning perspective, in other words, how traditional planning interventions (such as housing, neighborhood zoning plan, environmental impact assessment and master plan) were reframed as a resilience perspective or what kind of influence this reframing had on institutional practices, and finally, which outcomes are expected to promote urban adequacy to climate change.

The case was selected because it highlights one or more pivotal aspects of the politics of city planning, from how 
urban problems should be redefined within the social adaptation perspective, to how institutional practices across disciplines and agencies are organized to support resilience city planning practices. The case also highlights the barriers and opportunities for reconnecting city planning and environment.

\section{Sea level rise, extreme rainfall, storm surge, and weather related hazards}

Global sea level rise rose at an average rate of $1.7 \mathrm{~mm}$ per year over 1961-2003, and more recently (1993-2003) at an average rate of $3.0 \mathrm{~mm}$ per year (coastal tide gauge measurements confirm this observation). Nevertheless, it is unclear whether faster rate reflects decadal variation or an increase in the long-term trend, despite of satellite observations that became available increasing the accuracy of sea level measurements (Church et al. 2013).

In fact, since 1993, half of the SLR observations have been attributed to thermal expansion of the oceans even though other factors like ocean salinity and changes in the ocean circulation also contribute to spatial variability of the rates (Church et al. 2013; Meyssignac and Cazenave 2012).

There are few studies (Muehe 2010; Alfredini et al. 2008, 2012, 2014, 2015; Pezzoli et al. 2013a) exploring SRL variability in the Southeast Brazilian coastline, the records available (from 1940 to 2007) estimated that sea level had risen $3.2 \mathrm{~mm} \mathrm{yr}^{-1}$ in Cananeia (SP) and $3.6 \mathrm{~mm} \mathrm{yr}^{-1}$ in Rio de Janeiro (RJ), (Alfredini et al. 2008). According to Alfredini et al. (2008, 2015), in the harbor of Santos, tidal gauge suggest that mean sea level has risen at a rate of $1.2 \mathrm{~mm} \mathrm{yr}^{-1}$ over the past 30 years, with an increasing trend in the past decade.

In agreement with climate models, satellite data and hydrographic observations, sea level is not rising uniformly around the world. Additional factors such as ocean circulation patterns or land subsidence may be contributing to changes in local sea levels, in some regions rates are up to several times the global mean rise, while in other regions sea level is falling (Church et al. 2013).

In general terms, coastal cities are expecting the impacts of sea level rise; however heavy precipitation and storm surge will have important effects on coastal urban ecosystems, increasing the risk of floods and landslides, and enhancing the vulnerability of energy infrastructure, transportation, and telecommunications facilities (Young 2016). Important cities on the Brazilian coast, such as Rio de Janeiro (2010), Angra dos Reis (2010), Teresopolis (2011) and Florianopolis (2008, 2011, 2015), have been affected by landslide and flooding (caused by extreme rainfall and tidal conditions) that occur either individually or in combination (CEPED 2013).
Flooding and landslide can produce destructions of properties (with associated diseases and deaths), coastal lands saturation, contamination of distinct areas (with high levels of pollution including water supplies), inundation of wastewater treatment plants, submergence of rail lines and roadways (Young 2016).

Particularly, in Santos there is a strong topographical variation between the coastal plain and the Atlantic mountains. The mountain chain (Serra do Mar) is defined by a relief of $1100 \mathrm{~m}$ and the Atlantic coast plain is defined by a relief with an average elevation of $5 \mathrm{~m}$ above sea level and with low-lying bays and estuaries (average elevation of $\sim 1 \mathrm{~m}$ above sea level) (IPT 2005, 2009).

Because Santos is so low-lying and surrounded on almost all sides by water, more than $30 \%$ of population lives within $5 \mathrm{~km}$ of the coast and most of the population is concentrated in areas around rivers and the estuary. Only a relative small portion $(\sim 30 \%)$ of the population lives in central areas (inland) of the island (Alfredini et al. 2008, 2015).

Costal exposure is cumulative result of number of significant factors including: climate-induced SLR, tidal variation (seasonal high tides), wave climate (surface wind waves), currents and non-periodic water movement such as storm surges. The SLR is already having a significant impact on the southeast coast in the form of erosion, where retreat is occurring fastest from 2009 to the present year with an average variation of $\sim 0.67$ inches per year in extreme cases of SLR (i.e. Ponta da Praia neighborhood) (Alfredini et al. 2015).

When examining climate change impacts at global scale, SLR emerges as an issue of significant concern. Particularly, in the southern (mainly coastline) will experience an increase in coastal flooding which may contribute to infrastructural damages. Such a rise would generate inland water upwelling throughout much of south even as many coastal neighborhoods faced inundation. There is a significant concentration of highly vulnerable neighborhoods in Santos with SLR already having a significant impact on the soft boulder coast of the southeast, where coastal defense protect only $5 \%$ of the coastline (Alfredini et al. 2015).

Over the past two decades, some structural damages along the coast of Santos were caused by a combination of storm surge, high tide, and/or battering waves (Miller et al. 2012). In 1999, a high tide peaked at $1.6 \mathrm{~m}$ and reached the city making many streets impassable due to obstructions caused by flooding. In 2005, the region was struck again by a storm surge with waves of maximum 3 $\mathrm{m}$ and respective tidal rise of $0.80 \mathrm{~m}$ which caused damages to a seawall and inland flooding (Alfredini et al. 2008). 
In 2011, the city was affected by advancing seawaters where tides reached $1.6 \mathrm{~m}$ and hit the seawall (i.e. broke low walls along the beachfront in Ponta da Praia) and other types of infrastructure (i.e. obstruct of pedestrian or vehicular traffic) causing a power outage (Pupo 2011). In the same way, many areas of Santos were affected by a heavy rainfall in December 2012, with traffic interruption caused by trees that have fallen into the channels resulting in floods (Globo News-G1 2012). In 27th April, 2016, breaking waves exceeded three meters high and the winds reached nearly $90 \mathrm{~km} / \mathrm{h}$ (Globo News-G1 2016).

On the east (Santos estuary) and northeast (mangroves) the potential to undergo invasion tide is significant and probably will contribute to losses of coastal wetlands and mangroves along with the impacts of erosion and deposition (Alfredini et al. 2015). As shown by the simulation of the physical model and the cartographical assessment in Alfredini et al. $(2008,2015)$, the SLR will flood around $50 \%$ of the present Santos estuary mangroves and approximately $100 \mathrm{~m}$ of the beaches in 2100 .

Small, low-lying islands in the north (i.e. Bagres, and Barnabé islands), and barrier zones (e.g. Casqueiro, Pompeva, Paratininga, São Manoel, and Alemoa) would be swallowed by the sea or broken by incursions through weak points. The mangroves, already in retreat, would be swiftly beaten back. Inland lakes (i.e. Pompeba lake in São Vicente), invaded by higher pressure salt water from below, would also rise (Miller et al. 2012).

The potential future exposure of the city to storm surge under given sea level rise scenarios is not clear, but is important to highlight the city sits on porous limestone (sandy ground) where water table is close to the land surface (unsaturated zone) and where extreme precipitation eventually adds water into the groundwater (IPT 2009). Saturated conditions may extend above the water table as surface tension by holding water in the groundwater. It can generate inundation on the surface because of the water elevation is dependent upon the pressure. In case of storm surge event, the surface water cannot flow into the sea due to the action of momentary rise in sea level caused by storm (USGS 2016).

Thus, this study is framed as a medium resolution DTM for regional assessments and the modelling uses a project scenario from 0.5 to $2.0 \mathrm{~m}$ drawn from possible SLR and storm surge explanations provided in the literature (Rahmstorf et al. 2007, 2012a, b; Church et al. 2013). In addition, we considered Alfredini et al. (2015) that shown an increase in the wave significant height (Hs) in the period between 1950 and 2002, from an average value of $1.0 \mathrm{~m}$ to an average value of $1.3 \mathrm{~m}$.

Figure 1 presents the output of SLR modelling carried out for this study in Santos, based on a digital terrain model (DTM) $30 \mathrm{~m}$ scale resolution. It is important to highlight that the resolution of DTM is not sufficient for high-resolution detection and modelling sea-level change in detailed mode at a local scale as there are significant considerations in the vertical projections of the model that was considered but that could not be solved with available information.

\section{Results \\ Reframing urban space through typological categories}

The Fig. 1 presents a representation of the Santos Bay and estuary displaying residential and commercial addresses overlaid on the sea-level rise scenarios, the vulnerable areas to SLR/storm surges on the coast with neighborhoods facing the greatest percentage of infrastructure damages ranging from over $\sim 10 \%$ in the first scenario, and almost $30 \%$ in the last one.

Santos is highly vulnerable to SLR due to both its geomorphology and its built environment and infrastructure (IPT 2005, 2009; Alfredini et al. 2015). Different areas of the coastline and practically the entire estuary are vulnerable in different ways due to variation in land use (AGEM 2002) and population density (Young 2013). There are residential neighborhoods along oceanfront beaches with dense commercial and residential areas along the coastline, an important harbor with industrial activities along the estuary with stretches of coastal marshland and mangroves (Afonso 2006; Young 2010).

The land use in Santos is diverse throughout its coastal zone and the city is home to some of the densest settlement and largest commercial districts in the Baixada Santista Metropolitan Area (Afonso 2006). Each of these areas faces unique risks and demand different types of strategies to make them more resilient to coastal risks due to climate change (Miller et al. 2012).

To understand the range and nature of risks and vulnerabilities throughout the city, we identified a set of coastal area typologies representative of specific conditions. The typology serves as points of reference to analyze variation in coastal hazard exposure and land use circumstances, and it is also important for identification of vulnerabilities, risk, and potential strategies. The urban density may create additional coastal risks and vulnerabilities depending on the social stratification.

Through analysis of different zones of the city, nine types of areas were identified (Table 1). The following coastal area typologies represent a range of land use, environmental conditions and social stratification what not meant to be exhaustive of the types of coastal areas that exist throughout the city. The objective in the development of the coastal typology was the identification of a set of categories which can be used at local level as a starting point to understand the socio-economic circumstances, and local trends. 

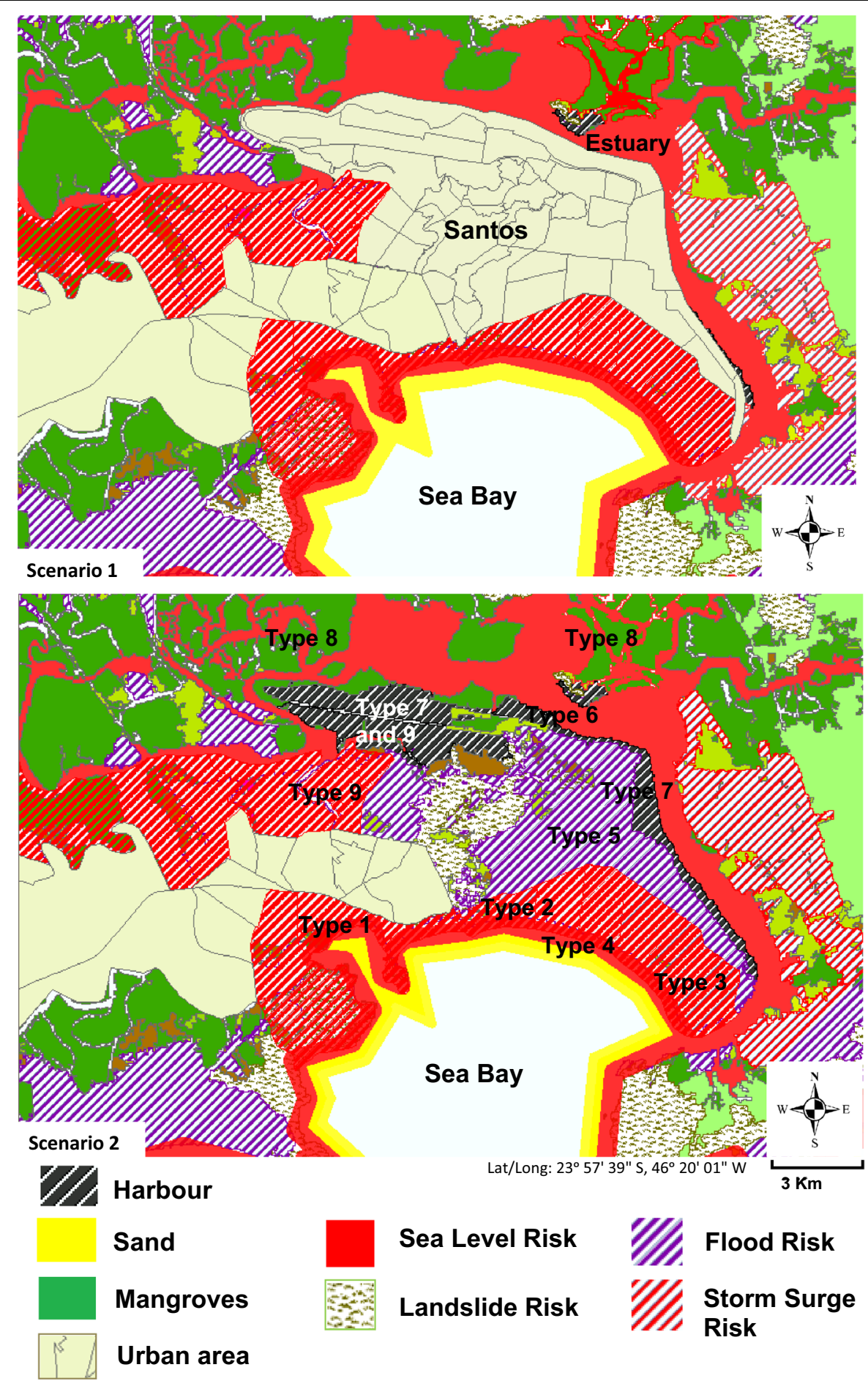

Sand

Sea Level Risk

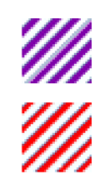

Flood Risk

Mangroves

Landslide Risk

\section{Urban area}

Fig. 1 Sea-level rise and weather related scenarios on Santos Coast City

During last decades different policy concepts have been utilized in order to monitor the structural changes in Santos related to land-use and also urban coastal areas, thus urban development of city has been driven by different motivations (AGEM 2014; Master Plan 2013).

One of the leading policies of growing in Santos was to increase the density of the urban structure in order to 


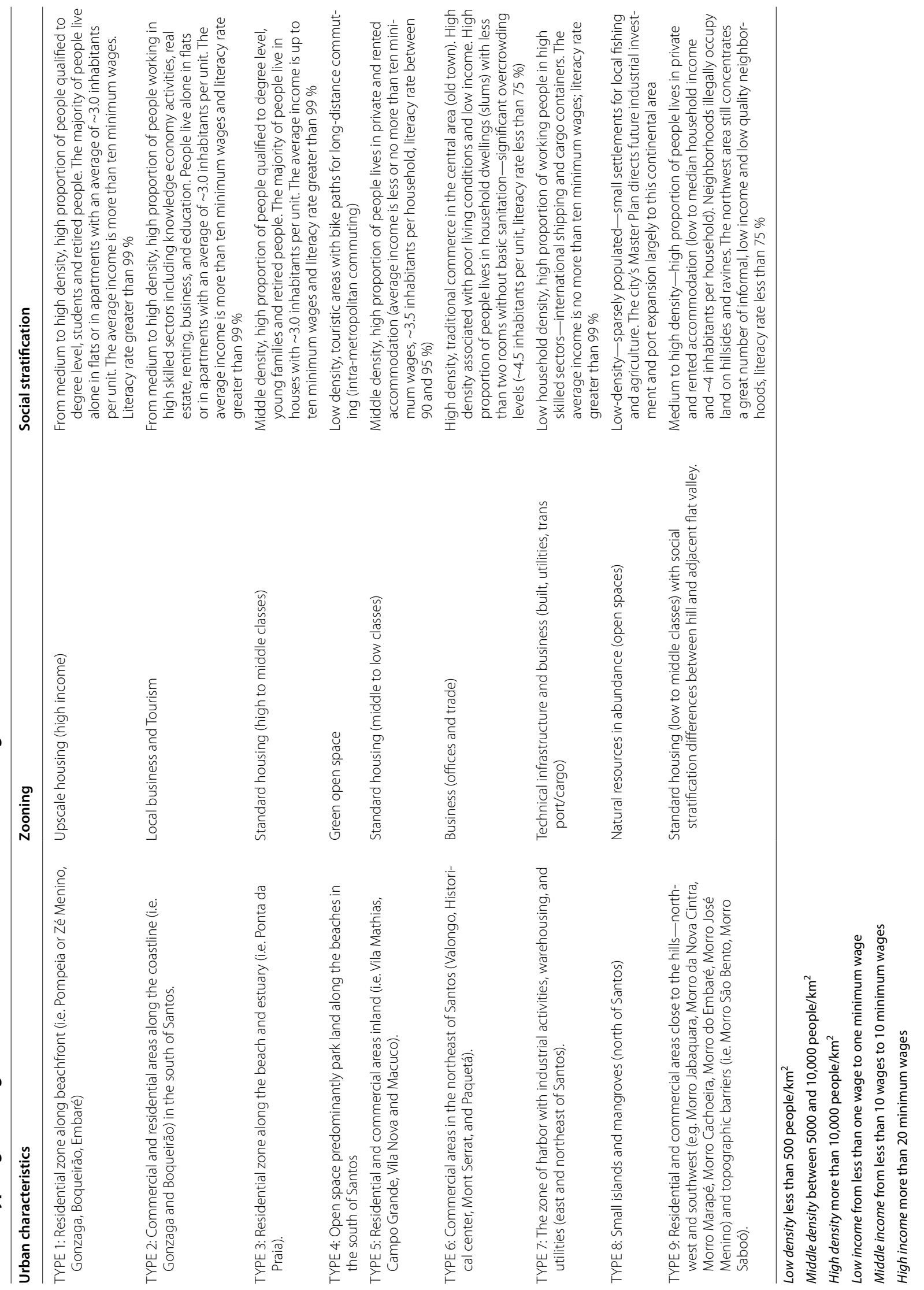


minimize both the urban expansion (due to lack of space) and investments in infrastructure (Master Plan 2013). These urban densification processes have intensified the building and planning of coastal areas close to the beaches (i.e. Gonzaga, Boqueirão, Embaré) where various interest groups and higher income citizens (above 20 minimum salaries) have acquired their properties (AGEM 2014).

In Santos, the beachfront areas are often strategic sites in urban development; the public spaces of mobility and infrastructure connection were clearly defined on the coastline (Cunha et al. 2006). Their usage has direct effects on the tourist and commerce image (represent unbuilt natural resources or green regions in the urban structure) and on the social status (locations of highprice housing) (Afonso 2006; Young 2010).

When analyzing growing disparities inside the city, the concept of periphery (or suburb) is far from being the most relevant. In contrast, concepts like segregation, polarization, and marginality have been applied to describe the phenomena of social exclusion (Santos 2014). The reason relates to the fact that Santos does not have a traditional center-periphery model or presents the usual concentric rings pattern (extremely common in Brazil).

The original center situated on the coastline was destroyed by a tsunami in 1541 and the implementation of the new center occurred along the estuary in the northeast of the island (Santos 2014). Nowadays, the surrounding cities (in metropolitan area) act as suburbs that contain the population overflow from Santos (Master Plan 2013; Miller et al. 2012).

As the city is an island which has no suburbs, the old center of the city remains concentrated along the estuary, but a touristic center was later seated in Gonzaga neighborhood (Type 2). The primarily residential and commercial zone (i.e. Valongo, Historic Center and Paquetá) is situated along the estuary (distant less than $500 \mathrm{~m}$ ) to which was subsequently added an adjacent area further northwest (i.e. Alemoa) connected by important traffic arteries (av. Presidente Getúlio Vargas, av. Martins Fontes, and av. Bandeirantes).

Despite of the historic center revitalization, that has been occurring since the mid-1990s, the central area has historically had a fairly low socio-economic status (Santos 2014), with social deprivation related to lack of infrastructure (substandard housing with a total population of $\sim 14,000$ habitants), basic services (continuous water, electricity supply, and garbage collection), and low median household income (around U\$ 50-250 per month) (SEADE 2010).

The index of social vulnerability (ISV) attested the socioeconomic immobility of almost all the residents of this central region, where local people continue to live in collective, overcrowded and abandoned housing (SEADE 2010). The opportunity structures offered by the state and real estate market are so limited that often promulgates mechanisms of social exclusion (Santos 2014).

Vila Nova and Macuco (Type 5) are residential neighborhoods around in the border of center and the portuary zone, compounded by old wetlands that were grounded. These older neighborhoods as well as Vila Mathias, and Campo Grande have no straight connections to the waterfront and beachfront and they present a template of Low Density Residential Zone (single-family units for middle class workers with average income of less than ten minimum wages).

The Harbor-district ${ }^{2}$. is situated directly on the estuary $(\sim 50 \mathrm{~m})$, close to the center of the city and connected by important traffic arteries (av. Cidade de Santos and Xavier da Silveira) with office buildings and facilities for $\sim 15,000$ workers. The access to the estuary channel by boat has a width of $130 \mathrm{~m}$ and depth of $13 \mathrm{~m}$; in the estuary the width is $100 \mathrm{~m}$ with depth of $\sim 12 \mathrm{~m}$. The wharf consists of 11,042 $\mathrm{m}$ in length and depth ranging between 6.6 and $13.5 \mathrm{~m} ; 521 \mathrm{~m}$ of pier for special purposes with a minimum depth of 5 and $1883 \mathrm{~m}$ for private use, and with depths of 5-11 m (Companhia Docas do Estado de São Paulo 2015).

According to Santos (2014), the urban space in Santos has reflected the contemporary economic and social dynamics around the socialization of wage labour with periodic oscillations of unemployment and growing precariousness. The action and inaction of the state is seen as an integral part of the genesis and growth of the city which to varying degrees proved to be unable or unwilling to stem the rise of inequality and marginality.

\section{Drivers of natural disturbances prone to anthropogenic amplification}

The city of Santos tend to be highly exposed to coastal flooding, whether due to changes in sea level rise, tidal waves or the effects of frontal systems. The urban

\footnotetext{
${ }^{2}$ Summary of the infrastructure of Santos's Harbor: 45 internal warehouses -34 on the right bank and 11 on the left bank of the estuary, and 39 external warehouses - that adds up to $516,761 \mathrm{~m}^{2}$, and a static capacity of 416,395 ton. 33 yards storage, internal and external-totaling 124,049 $\mathrm{m}^{2}$ - static capacity of 99,200 ton. The tankage facilities include: 39 tanks (to $149,726 \mathrm{~m}^{3}$ ) and 131 tanks (to $112,484 \mathrm{~m}^{3}$ ) in Barnabé Island; 24 tanks (to $2712 \mathrm{~m}^{3}$ ) and 28 tanks (to $14,400 \mathrm{~m}^{3}$ ) in Pier do Saboó; 10 tanks (totaling $105,078 \mathrm{~m}^{3}$ ) and 50 tanks (to $390,780 \mathrm{~m}^{3}$ ) in the Alamoa terminal. There are more than six specialized terminals with containers for industries (e.g. fertilizers and sulfur), and agricultural products (soya, sugar, corn) TECON, TEMAG, TGG-with hundreds of electric cranes and conveyors for shipment of the products.
} 
expansion along the coast often results in ground sealing of coastline which disturbs natural erosion dynamics and tidal movements and increases flood risk in close proximity to the river channels susceptible to storms (Alfredini et al. 2008, 2012, 2014, 2015).

The natural course of the rivers has changed during regulation of the river channels (in the 70s) and the natural system of rivers was transformed in a channels system which crosses the entire city, channeling the water from the bay to the estuary. For the early, they were designed to carry both waste and storm water, more recently (beginning of this century) the sewage ${ }^{3}$ emissaries have been embedded (encapsulated) within the channels (Abessa et al. 2012). The channels can discharge both to the bay and the estuary; during high tide, one side of the channel is blocked and the remaining water is stored in the channels which are not enough to prevent the flooding of urban area. During low tide, channels are opened and water can flow towards the estuary and the bay (Master Plan 2013).

Santos tends to have a high proportion of impervious cover (all urban areas except some hills), which is a key determinant of energy flux portioning. Basically, during the day the sea surface warms less rapidly than terrestrial surfaces and this suppresses sensible and latent heat fluxes. During the evening and night the sea surface cools less rapidly than terrestrial surfaces and this enhances the sensible and latent heat loss (Miller et al. 2003).

Responding to regional air mass activity, the vertical temperature and humidity gradients may be influenced by the sea to promote evaporation with storage heat fluxes ${ }^{4}$ and greater heating of air and substrate (e.g. heat island effect) mainly in the inland areas (Type 5), and constant breezes on the waterfront (Type 1,2 and 3). However, it is important to remember that on the beachfront tend to be denser (Type 1 and 2) than other geographical settings (Type 5 and 3), with the massive presence of multi-family buildings (a barrier of tall buildings on the beachfront).

The seasonality exerts strong influence on storm activity in Santos, ${ }^{5}$ warm surface temperatures and strong winds are favorable for large heat exchanges between the ocean and atmosphere (Alfredini et al. 2013). Rain clouds

\footnotetext{
${ }^{3}$ Submarine sewage outfalls have been historically used in Brazil as a solution for urban effluents, in special due to economic aspect. Nevertheless, the release of untreated sewage into the ocean does not constitute an adequate environmental practice; the effluents should be treated in order to remove contaminants and pathogenic organisms (Abessa et al. 2012).

${ }^{4}$ These energy exchanges include latent heat, sensible heat, and radiative exchanges (Miller et al. 2003).

${ }^{5}$ The region is known for its orographic rainfall (subject to severe precipitation), caused by moisture fronts from the Atlantic Ocean that collide with Serra do Mar (Pezzoli et al. 2013b).
}

follow warm waters affecting regional precipitation patterns, and the shift in the large tropical rain clouds, caused by phenomena like El Niño for example, alters the typical pattern of the jet stream (Boers et al. 2014a; Amador 2008). The tropical convective systems disrupt upper air patterns and modify the winds that blow on them on a much larger scale, characterizing storms scenarios (Pezzoli et al. 2013b). Increased evaporation means more water vapor in the air and more energy ready to be liberated in the tropical cyclones (or thunderstorms) as water vapor condense (Brigatti and Sant'Anna Neto 2008).

In short, the meteorological key to understanding the regional power of tropical cyclone is the process of evaporation and condensation of water, but the risk is more than simply exposure to hazard. The juxtaposition between large scale climate variability, for example, the combined effect of rainfall and high tides can generate the classical phenomenon called "tidal flooding" (Pezzoli et al. 2013b). Besides, the landscape and debris flow (Pezzoli et al. 2013b), and the settlements typology and environmental exploitation (IPT 2009) culminates in heightened risk and potential hazard which arises in different neighborhoods, depending on where these events are occurring (Pezzoli et al. 2013b).

For example, floods can occur in Gonzaga and Embaré (Type 1 and 2) that are situated in front of Atlantic Ocean and in close proximity to the channels (emissaries). The crest of wave which is $2 \mathrm{~m}$ above mean sea level can reach Ponta da Praia (Type 3) susceptible to floods caused by storm surge and frontal systems because is in close proximity of both the sea and estuary entrance.

Some neighborhoods are located along the estuary such as Valongo, Historical center, and Paquetá (Type 6) and given how floods propagate downstream through catchments, this also make them vulnerable. There are pockets throughout the northwest (i.e. Alemoa is $1.5-2 \mathrm{~m}$ above mean sea level) that are not adequately protected where a rise in sea level of less than $1.5 \mathrm{~m}$ can cause flooding.

Although most sections of harbor are built to withstand water level increases of as much as $3 \mathrm{~m}$ above mean sea level, storms can reach some flat areas along the harbor in the docklands (Type 7) and affect directly or indirectly wharf activities, for example, transport of refined oil, shipments of chemical and agricultural products (commodities) and industrial products (e.g. agricultural equipment, trucks, machinery and steel bars), depending on the rainfall rates, persistent trend winds, and infiltration through the estuary caused due to sea level rise, and action of the wind blowing over the water (Pezzoli et al. 2013a).

Moreover, Santos is surrounded by hills (e.g. Morro da Nova Cintra, Mont Serrat, Morro do Embaré, Morro José Menino) and topographic barriers (i.e. Morro São Bento, 
Morro Saboó) that serve to enhance local risks (Type 9), depending on the intensity of storm and respective precipitation (IPT 2005) caused by frontal systems resulting in landslides.

The extensive interventions in biophysical system such as degradation of the environment, subsidence, and salinization $^{6}$ have implicated in the reinforcement of urban hazards by reducing the ecosystem resistance (Nicholls et al. 2007). Coastal areas have been strongly degraded or altered as a consequence of urbanization (Type 1 and 2) and harbor activities along the estuary (Type 7). Dredging of soils with high concentration of clay and water, destruction of mangroves and wetlands (Type 8) were common problems in the past. ${ }^{7}$ On the beachfront (Type 1 and 3) the excessive pumping groundwater, dredging and dissolution of sand soils caused by built processes associated to natural fluid flow in the subsurface have caused subsidence at the surface which is evident through the sloping appearance of many buildings. The submergence in combination with sea level rise can be one of the most important contributing factors for severe flooding on the coast (Type 1, 3 and 4).

Furthermore, it is extremely important to realize that shoreline changes induced by erosion and accretion are natural processes; ${ }^{8}$ it makes part of the dynamic of the coast, but in Santos there is high evidence that urbanharbor-induced factors surpass natural coastal erosion in the entrance (Type 3 e 7) and along the estuary (Type 8). The development of harbor along the estuary of Santos within river catchments and watersheds (river damming and diversion) and offshore (dredging) in combination with these natural phenomena (erosion and accretion) often exacerbate coastal erosion in Ponta da Praia neighborhood (Type 3).

\section{Challenges for prioritizing climate change adaptation and urban resilience}

Santos has an institutional structure with a strong focus on preparedness and risk reduction through the Civil Defense Department which focuses primarily on risk prevention, preparedness and adaptation activities (Fig. 2). Investments have been made to improve government processes of risk management through the emergency management plan coordinated by the mayor's

\footnotetext{
${ }^{6}$ Salinization of surface waters in estuaries is also caused by SLR (Allison et al. 2003)

7 The eutrophication of the estuary is caused by sewage (Abessa et al. 2012).

8 They occur in response to smaller-scale (short-term) events, such as storms, regular wave action, tides and winds, or in response to large-scale (long-term) events that may significantly alter sea levels (rise/fall) and tectonic activities that cause coastal land subsidence or emergence (Prasetya 2007).
}

office, along with the Police and Fire departments that have been involved in the strategic planning for flood and landslide hazards.

The organizations undertake public education campaigns and direct community engagement in high risk areas and works in a pre-emptive manner by removing at risk populations both in advance of and during the impact of events. Recently, a complementary Law (No $778 / 2012$ ) was passed giving municipal authorities the jurisdiction to pull down illegal construction that does not comply with land use controls as a measure towards preventing risky neighborhoods.

The overall approach to risk has focused on planning for existing hazards and vulnerability, but with little consideration of future climate variability and its potential impacts. Despite the efforts, more than 35,000 families live on the hills where approximately 11,000 people live at risk and $~ 5000$ household are located in high risk sites. Under these circumstances, more than 780 families should be immediately removed (IPT 2009).

The costs of intervention in risk areas reach $\sim \mathrm{U} \$$ $6,078,858.54$ and were estimated by the IPT in 2009 (updated for today). The municipal outlook is changing as the climate change becomes clearer, reflecting an overall change in municipal priorities from a focus on mitigation to adaptation which demand financial resources around U\$ 76,271,213.78, specified according to Table 2.

General consensus exists between institutions involved concerning the relevance of space networks at risk situations, despite a considerable dispute on the prominence of each distinct situation such as floods or landslides. For example, the threatened spaces indicate the existence of great heterogeneity in the classes of poor individuals, mainly in reach areas beyond the limits of risk areas, with substantial differences, on average, to middle-class individuals.

Certain types of neighborhoods are systematically associated with better living conditions, employment and income. But normally, network mobilization by individuals presents important characteristics (e.g. low income and education level) and regularities associated with social mechanisms, understood as regular patterns (e.g. land irregularity, lack of infrastructure, excessive density) that trigger or cause certain unexpected results such as disasters.

Landslides ${ }^{9}$ and flooding in Santos are caused by a combination of factors including geomorphology, intense

\footnotetext{
${ }^{9}$ In Santos, nineteen risk areas were mapped and according to the records, it is a form of mass wasting that includes a wide range of ground movements, such as rockfalls, deep failure of slopes, and shallow debris flows (related to soil destabilization and instability of natural slopes). Because of that, when the limit equilibrium is exceeded, few precipitations may produce apparently disproportionate effects (IPT 2005).
} 


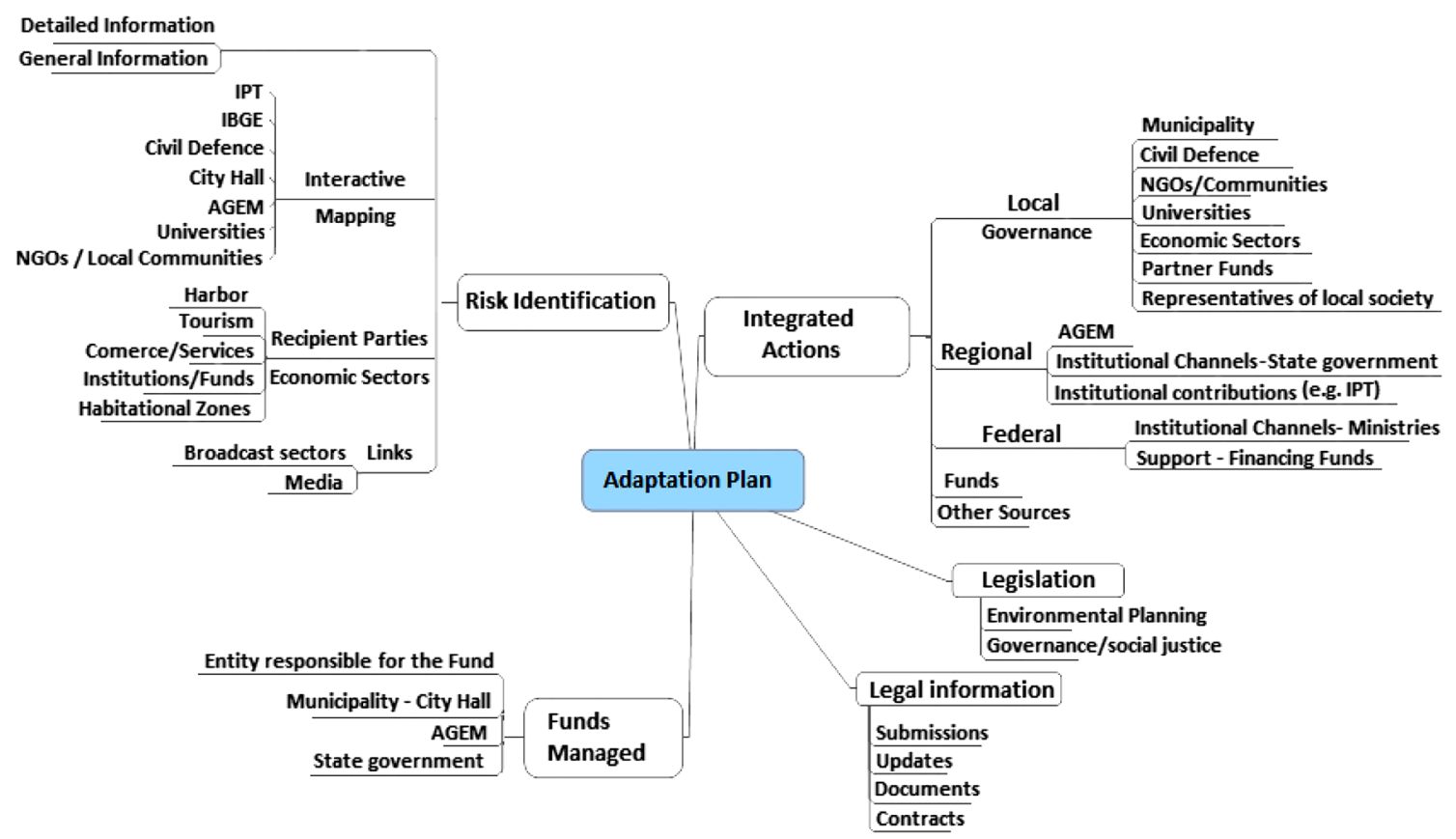

Fig. 2 Conceptual framework for understanding the urban planning interactions Table 1

Table 2 Costs of intervention

\begin{tabular}{lllr}
\hline Housing characteristics & Households (units) & Legal state & Cost (U\$) \\
\hline Land Irregularity $^{\mathrm{a}}$ & 11,715 & Regularization (need to regularize) & $2,461,134.45$ \\
Lack of infrastructure & 7830 & Urban renovation & $54,745,098.04$ \\
Households without toilet & 1274 & Housing reform & $4,023,377.65$ \\
Excessive density & 4900 & Housing reform & $8,962,745.10$ \\
Prone areas & 5000 & Removal and relocation & $6,078,858.54$ \\
Total & 30,719 units & & $76,271,213.78$ \\
\hline
\end{tabular}

a (public or private land occupie-not properly licensed-not according to the town planning and environmental legislation)

Institute for Technological Research-IPT (2009)

rainfall, deforestation and illegal occupation. These mechanisms explain to a great extent the heterogeneity of threatened areas, and mediate the individual's access to opportunities, infrastructure, social services, preparedness and safety assistance (IPT 2005). They contribute decisively to the production (and reproduction) of urban risk. This is the case of Vila Progresso with 900 families ( 2500 people) in undefined situation on the top and between unsafe hills (i.e. foot of the hills), where runoff is particularly high because of the slope (IPT 2005, 2009).

Considering these circumstances, the scarcity of vacant land and difficulties for community facilities stands as the main restriction for a feasible "Integrated Local Plans", since the habitants cannot be accommodated in their places of origin, putting pressure on local infrastructure and services for 9568 housing units, mainly because the system response normally remains undefined in such circumstances (IPT 2009).

Despite difficulties, from 2009 to 2012, the municipality, led by the mayor, has relocated families from high risk landslide areas. The most relevant programs include "The Urbanization, Regularization and Integration of Informal Neighborhoods Program" and "The Improvement of Living Conditions Program". The relocation effort to remove all families from the high and very high risk areas is ongoing and the main objective is the prevention of risk through the regularization of informal neighborhoods, the provision of basic services, safety conditions, and also the improvement of sanitary conditions. The recovery of the forests in these areas will play a key role in preserving the soils properties with support interventions for land regularization (Miller et al. 2012). 
Improvements include the paving of streets, the construction of rain treatment systems or contention walls, physical and legal integration of slums and or such neighborhoods into the existing urban fabric through specific programs such as "Special Improvement Program", "Urbanization of Slums Program" (Miller et al. 2012), and the project "Santos New Times" (Santos 2014).

The actions also aims at strengthening the capacity of populations located in risk or inappropriate areas through the "Program Prevention and Eradication of Risks in Precarious Neighborhoods" which consists of three basic components: (1) the elaboration of a hazard risk maps in informal neighborhoods (AGEM 2002), (2) preparation of a Municipal Risk Reduction Plan, by establishing integration of safety measures with sanitation, social housing and regularization of informal neighborhoods in order to articulate risk reduction strategies, (3) mobilizing financial resources for landslide risk reduction in informal neighborhoods (Miller et al. 2012; AGEM 2002, 2014).

For example, approximately 24 neighborhoods of the northwest, covering over 18,000 families or around 150 thousand inhabitants would be benefited directly and indirectly with the realization of macro-drainage to eliminate flooding prone areas and replacement of substandard housing through urban renewal, increasing the supply of spaces and community facilities of education, health, culture, and leisure (IPT 2009).

But some doubts remain on the continuity of measures in different political and economic scenarios that normally change over time in Brazil. Besides, it is important to be clear about adaptation procedures based on actions that should not reinforce existing inequalities between communities, sectors or neighborhoods.

\section{Overcoming adversities for achievement of better responses}

As with other social issues, the policies and public adaptation measures giving significance to future impacts of climate change and responses needs to be created and connected to urban planning in a wider perspective, internalizing these aspects for urban development. This section provides an overview of the gaps and limitations for each of the two hazard typesfloods and landslides.

The range of possible hazards mitigation and vulnerability reduction measures for managing environmental risks are broad, but as noted above they succeed best when there is a comprehension of the local typology, scale, type of the risk, and the opportunity that can come from overcoming the risk.
Three factors are particularly important to shape the responses in Santos. First, the role of municipal and political leadership would be extremely important through a resilience network, but formally this kind of network does not exist. In the same way, an integrated urban management and health as mainstream planning practice should embrace adaptation process (led by the city hall, civil defense and the fire brigade), becoming a headline issue in development practice.

Second, the exploitation of strategic opportunities should be considered based on climate projections of extreme rainfall events and sea level rise simulations. Despite, climate change means living with high levels of uncertainty and surprise events, there are not specific relationships available connecting historical precipitation events and environmental conditions (e.g., long-term precipitation conditions, intensity of rainfall, return periods) to past flood events. The relevant precipitation thresholds are not available and are extremely important for identification of future change in landslide and flood hazards situations (Miller et al. 2012).

In the same way, data from tide gage stations of Santos Bay was not available for a local and most precise SLR analysis (Alfredini et al. 2014), for this reason, the municipality has not considered potential changes in local circulation of ocean currents, erosion and accretion dynamics, and saltwater intrusion (with salinity levels) in the estuary.

Third, the complexity of the climate change issue has meant that the city should consider a variety of different responses that depend on local characteristics. Further examination of environmental hazards related to forest cover loss, urban land use development, soil erosion, and specific historical extreme events (e.g. storm surge, heavy rainfall) may help increase understanding in how extreme events contribute to landslide hazard and floods.

\section{Questions that still need to be answered through a multi-level process of interaction}

This paper has reviewed some of the complex interactions of climate variability marked by ocean changes and weather patterns in different typological zones of Santos. It was clear that disaster risk reduction is an integral objective of environment-related policies and plans, including for land use, natural resource management and climate change adaptation. Adaptation interventions require capturing dynamic variables that change over time and place, and understanding the decision-making processes at the household level leading to action and sustainable change.

In general terms, urban planning tools have followed a logic model of cause-effect (e.g. decision and respective 
impact). Uncertainty about the timing and intensity of climate events highlights the importance of learning process and the fact that long-term adjustments may be different from the response to short-term hazards (Villanueva 2011).

When monitoring and assessing impacts, it needs to be kept in mind that in some circumstance the decision making processes seem to diverge and spread in different directions, so as to render a judgment on a set of legal issues without looking at all aspects involved. This process can result in different agencies using different methods for evaluating adaptation options (Villanueva 2011). Therefore, it can explain why civil defense and fire brigades need to chase the risks caused by decisions taken by different institutional and organizational bodies.

The focus on institutional process, learning and change in behavior and actions of public institutions (i.e. urban planning department, civil defense, fire brigade) makes an innovative learning case for assessing and evaluating adaptation interventions. However, this does not explicitly address existing behaviors, or evaluate what the drivers of change represent, nor the individuals, organizations (e.g. real estate market) or community's decisionmaking processes that lead to action.

Indeed, this is a reflection of the fact that adaptation measures are not recognized by many entities as an urban planning process (e.g. water and sanitation companies). Usually, trading has embedded outcome mapping progress only through markers of economic costs and financial frameworks that definitely is not logical in social economic terms for an integrated system (i.e. environment, health, population welfare and safety).

In other words, this may not be enough to measure what really has been changed and the efficiency of measurements, but why and where change has been taken. We recognize that for an urban resilient reality, adaptation approach needs to be combined with urban approaches accordingly to urban typologies, but within a more ethical context in which engagement, commitment, and education are also involved.

For example, recent investment initiatives (e.g. PreSalt) indicate that an expansion is expected for the harbor of Santos; therefore, some important questions still remain: The expansion of the port should take place over the mangroves and remaining areas of the estuary? What kind of urban interventions should occur given the scenario presented?

\section{Conclusion}

We could describe the city of Santos making an analogy to Harvey (2003) in "Paris, capital of modernity", where he describes the physical distances between different classes as a reflection of material conquest and moral distance: "there is a mode of being which reveals what you are, what you do, where you come from, and what you are after". For Harvey (2014), the separation of social classes exists as both aspects social and environmentally ("spatial ecologies").

In this perspective, we can see the city of Santos as a spatial pattern of social relations and a moral order with few variations. Urban beachfronts have typically been sites of heavy development and often are sites of richest people (almost an exclusive space). On the other hand, the poorest or socially excluded live in the hills or in areas far away beachfront. The working middle class is clearly established between these spaces, interwoven by trade and services that support the Harbor and tourist area.

Despite of that, support structures have been created for adaptation measures through more accessible funding for urban projects, programs, dissemination of information and warning. Mechanisms for data collection, storage and dissemination have been created and improved for better climate monitoring, risk planning, and information sharing.

There is evidence of leadership in urban interventions related to climate change, including policy strategies, adaptive capacity, and risk management practices, which have been revised over time to better address changing risk contexts (Miller et al. 2012).

Besides, learning processes are central in the institutional framework, mainly in shaping the capacities and outcomes of urban resilience and disaster risk management. The municipality has demonstrated capacity to change local laws and regulations to improve regulatory system (IPT 2009).

However, aligning efforts with the private sector and society will be crucial to deliver adaptive response with an efficient use of natural resources (Morchain 2012). Despite on-going community engagement, most of the urban decision-making takes place within the institutional hierarchy of the municipality (Santos 2014) and there is a heavy focus on settlements relocation as the principal strategy for risk reduction in Santos (IPT 2009).

In part, the institutional planning control is a reflection of community's reaction, an overall fear of leaving the original domicile to be resettled in a new location without the same urban infrastructure. It is necessary investment in drainage, sanitation and waste removal services, and improved implementation of land use and urban planning laws (horizontal and vertical cross-scale) to integrate the risk management process.

Recognition of how climate change is likely to influence other development priorities may be a first step. For this reason, linkages between urban planning and environmental management are essential prerequisites to combine risk management and planning across all neighborhoods. An integrative approach to the challenges 
involved would help to avoid conflicts between measures designed and implemented by different organizations, as well as between different objectives such as mitigation and adaptation to assist in the design of integrated responses (Morchain 2012).

The municipal boundaries of Santos within the larger urban conglomeration of Baixada Santista also require attention because the municipal governments and respective civil defense do not formally collaborate for risk management integration (Miller et al. 2012).

It is important to highlight that the Baixada Santista Metropolitan Area is diverse in demographic, socioeconomic and institutional framework, yet many municipalities are struggling with similar challenges caused by urban growth and weak capacities in urban planning: (1) inadequate provision for public services and infrastructure; (2) lacking information and integrated actions.

As mentioned by Miller et al. (2012), particular attention should be paid to the level of engagement and liaison between the government and private sector (i.e. policies and projects) in managing climate risks, uncertainties and strengthening climate services. These include largescale infrastructure projects, transport networks (e.g. bike paths with public transport), major land use planning initiatives, urban development master plans and others, which play a key role in underpinning economic development and poverty reduction.

It is still necessary to develop cross-scale integration of risk management practices and to improve budgetary resources and climate financing for long-term recovery and building resilience against climate change hazards. The ultimate goal of the initiative should be to strengthen local adaptive capacity and to increase urban resilience through mainstreaming climate change adaptation into current planning systems and achievement of knowledge networks.

The establishment an inter-agency coordination can produce significant outcomes: (1) strengthening urban local governments through capacity building and better financial management to ensure a proactive and forward-looking system of risk governance; (2) management capacity enhancement in order to identify gaps of land use planning; (3) consolidation of capacity building efforts through training programs (4) improvement of data collection and dissemination of information to orient decisions at municipal and intra metropolitan levels; (5) increment of confidence on the downscaling of climate change models and climatic data (collect data and benchmarks for the city-region) for fostering cross learning among different actors and entities; (6) consideration of urban typologies as a tool for identification of climate risk providing policy analysis and support for all metropolitan region through applied research (risk-sensitive zoning); (7) identifying concrete mechanisms and strategies for enhancement of the city's capacity in terms of designing strategies through specific municipal budget allocations (sharing a common vison of climate change adaptation action).

\section{Competing interests}

The author declares that she has no competing interests.

Received: 30 June 2016 Accepted: 8 September 2016 Published online: 17 September 2016

\section{References}

Abessa DM, Rachid BR, Moser GA, Oliveira AJ (2012) Efeitos ambientais da disposição oceânica de esgotos por meio de emissários submarinos: uma revisão. O Mundo da Saúde 36:643-661 (in Portuguese)

Afonso CM (2006) A paisagem da Baixada Santista. Ed Edusp: 309 (in Portuguese)

AGEM (2002) Programa Regional de Identificação de áreas críticas de inundações, erosão e deslizamentos da Região Metropolitana da Baixada Santista_PRIMAC. http://www.agem.sp.gov.br. Accessed May 2016). (in Portuguese)

AGEM (2014) Agência Metropolitana da Baixada Santista. Plano Metropolitano de Desenvolvimento Estratégico da Baixada Santista 2014-2030:161 (in Portuguese)

Alfredini P, Arasaki E, Amaral RF (2008) Mean sea-level rise impacts on Santos Bay, Southeastern Brazil_physical modelling study. Environ Monitor Assess 144:377-387. doi:10.1007/s10661-007-0001-z

Alfredini P, Pezzoli A, Cristofori E, Dovetta A, Arasaki E (2012) Wave and tidal level analysis, maritime climate change, navigation's strategy and impact on the costal defenses - study case of São Paulo State Coastline Harbor Areas (Brazil). Geophys Res Abstracts EGU 14:10735

Alfredini P, Arasaki E, Pezzoli A, Fournier CP (2013) Impact of climate changes on the Santos Harbor, São Paulo State (Brazil). Int J Mar Navig Saf Sea Transp 7(4):609-617. doi:10.12716/1001.07.04.17

Alfredini P, Arasaki E, Pezzoli A, Arcorace M, Cristofori E, de Sousa WC (2014) Exposure of Santos Harbor metropolitan area (Brazil) to wave and storm surge climate changes. Water Qual Expo Health 6:73. doi:10.1007/ s12403-014-0109-7

Alfredini P, Arasaki E, Pezzoli A (2015) The impacts of sea level rise in Santos Harbour (Brazil) for next decades. E-proceedings of the 36th IAHR World Congress The Hague, the Netherlands, p 12

Allenby B, Fink J (2005) Toward inherently secure and resilient societies. Science 309:1034

Allison MA, Khan SR, Goodbred SL, KuehI SA (2003) Stratigraphic evolution of the late Holocene Ganges-Brahmaputra lower delta plain. Sediment Geol 155:317-342

Amador JA (2008) The Intra Americas seas low-level jet (IALLJ) Overview and future research. In: Gimeno L, Garcia R, Trigo R (eds) Trends and directions in climate research. New York Academy of Sciences, New York

Boers N, Bookhagen B, Marwan N, Kurths J, Marengo J (2013) Complex networks identify spatial patterns of extreme rainfall events of the South American monsoon system. Geophys Res Lett 40:4386-4392. doi:10.1002/grl.50681

Boers N, Rheinwalt A, Bookhagen B, Barbosa HMJ, Marwan N, Marengo J, Kurths J (2014a) The South American rainfall dipole: a complex network analysis of extreme events. Geophys Res Lett 41:7397-7405. doi:10.1002 /2014GL061829

Boers N, Donner RV, Bookhagen B, Kurths J (2014b) Complex network analysis helps to identify impacts of the El Niño Southern oscillation on moisture divergence in South America. Clim. Dynamics. 45(3):619-632. doi:10.1007/s00382-014-2265-7

Boonstra WJ (2016) Conceptualizing power to study social-ecological interactions. Synthesis, part of a special feature on exploring social-ecological resilience through the lens of the social sciences: contributions, critical 
reflections, and constructive debate. Ecol Soc. 21(1):12p. doi:10.5751/ ES-07966-210121

Brigatti N, Sant'Anna Neto JL (2008) Dinâmica e Variações do Nível do Mar na Geração de enchentes, inundações e ressacas no litoral norte Paulista. Revista Formação 2(15). Especial 20 anos. (in Portuguese)

Carvalho LMV, Jones C, Liebmann B (2002) Extreme precipitation events in southeastern South America and large-scale convective patterns in the South Atlantic convergence zone. J Clim 15:2377-2394. doi:10.1175/1520-0442(2002)015

Carvalho LMV, Jones C, Liebmann B (2004) The South Atlantic convergence zone: persistence, intensity, form, extreme precipitation and relationships with intraseasonal activity. J Clim 17:88-108. doi:10.1175/1520-0442

CEPED - CENTRO UNIVERSITÁRIO DE ESTUDOS E PESQUISAS SOBRE DESASTRES (2013) Atlas Brasileiro de Desastres Naturais 1991 a 2012. Volume Brasil, 2. Edição revisada e ampliada por CEPED-Universidade Federal de Santa Catariana. (In Portuguese)

Chiang JCH, Vimont DJ (2004) Analogous Pacific and Atlantic meridional modes of tropical atmosphere-ocean variability. J Clim 17:4143-4158. doi:10.1175/JCLI4953.1

Church JA, Clark PU, Cazenave A, Gregory JM, Jevrejeva S, Levermann A, Merrifield MA, Milne GA, Nerem RS, Nunn PD, Payne AJ, Pfeffer WT, Stammer D, Unnikrishnan AS (2013) Sea level change. In: Stocker TF, Qin D, Plattner GK, Tignor M, Allen SK, Boschung J, Nauels A, Xia Y, Bex V, Midgley PM (eds) Climate Change 2013: The Physical Science Basis. Contribution of Working Group I to the Fifth Assessment Report of the Intergovernmental Panel on Climate Change, Cambridge University Press, Cambridge

Companhia Docas do Estado de São Paulo (2015) Relatório Anual e Demonstrações Contábeis. http://www.portodesantos.com.br/relatorio.php (Accessed May 2016)

Corburn J (2009) Some challenges for healthy city planning Toward the healthy city: people, places, and the politics of urban planning. Massachusetts Institute of Technology, Cambridge, pp 1-24

Cosens BA (2013) Legitimacy, adaptation, and resilience in ecosystem management. Insight, part of a special feature on law and social-ecological resilience. Ecol Soc 18(1):9

Cunha JM, Jacob AAE, Young AF (2006) Dinâmica Demográfica Intrametropolitana na Região Metropolitana da Baixada Santista, no período pós 1970. In: Novas Metrópoles Paulistas: População, Vulnerabilidade e Segregação. Org. José Marcos Pinto da Cunha. Sitta Gráfica e Editora Ldta. Campinas (SP), Brazil. (in Portuguese)

Dodman D, Dalal-Clayton B, McGranahan G (2013) Integrating the environment in urban planning and management. Key principles and approaches for cities in the 21st Century. United Nations Environment Programme. International Institute for Environment and Development (IIED), p 84

Ernstson H, van der Leeuw SE, Redman CL, Meffert DJ, Davis G, Alfsen C, Elmqvist T (2010) Urban transitions: on urban resilience and human-dominated ecosystems. Ambio 39:531-545. doi:10.1007/s13280-010-0081-9

Espinoza JC, Marengo JA, Ronchail J, Carpio JM, Flores LN, Guyot JL (2014) The extreme 2014 flood in south-western Amazon basin: the role of tropical-subtropical South Atlantic SST gradient. Environ Res Lett 9(12):9. doi:10.1088/1748-9326/9/12/124007

Gasparro MR, Sousa ECPM, Giordano F, Argentino-Santos RC (2008) Occupation history of the Santos Estuary. In: Neves R, Baretta JW, Mateus M (eds) Perspective on integrated coastal zone management in South America. IST Press, Portugal, p 590

Gilmer B, Ferdaña Z (2012). Developing a framework for assessing coastal vulnerability to sea level rise in Southern New England USA. In: Otto Zimmermann K (ed) Resilient cities 2 local sustainability 2, Springer, Berlin, p 25-52

Globo News-G1 (2012) Chuva forte causa estragos e deixa cidades do litoral de SP inundadas. http://www.g1.globo.com/sp/santos-regiao/noticia/2012/12/chuva-forte-causa-estragos-e-deixa-cidades-do-litoral-desp-inundadas.html. Accessed Apr 2016)

Globo News-G1 (2016) Mar invade avenida da praia e ressaca destrói muretas na orla de Santos, SP. http://www.g1.globo.com/sp/santos-regiao/noticia/2016/04/mar-invade-avenida-da-praia-e-ressaca-destroi-muretas-naorla-de-santos-sp.html. Accessed May 2016

Harvey D (2003) Paris, capital of modernity. Routledge, New York, p 360

Harvey D (2014) Seventeen contradictions and the end of capitalism. Great Britain by Clays, Bungay, p 314
IBGE (2010) Censo Demográfico 2010: Resultados do Universo-Indicadores Sociais Municipais. Ministério do Planejamento, Orçamento e Gestão Instituto Brasileiro de Geografia e Estatística-Diretoria de Pesquisas Coordenação de População e Indicadores Sociais Estudos e Pesquisas Informação Demográfica e Socioeconômica. Número 28. (Published in Portuguese in 2011). http://loja.ibge.gov.br/indicadores-sociaismunicipais-uma-analise-dos-resultados-do-universo-do-censo-demografico-2010.html. Accessed Apr 2016

IBGE (2015) Estimativa da População 2011-2015. In Portuguese. http:// ibge.gov.br/Estimativas_de_Populacao/Estimativas_2015/estimativa_ dou_2015_20150915.pdf. Accessed Apr 2016

INPE_-Instituto Nacional de Pesquisas Espaciais (2016) Fenômeno El Ninõ já sinaliza seu enfraquecimento no Pacífico Equatorial. http://www.enos. cptec.inpe.br/and, http://enos.cptec.inpe.br/artigos/pt. Accessed Apr 2016

IPCC (2014a) Climate change 2014: impacts, adaptation, and vulnerability. Part A: global and sectoral aspects. Contribution of Working Group II to the Fifth Assessment Report of the Intergovernmental Panel on Climate Change In: Field CB, Barros VR, Dokken DJ, Mach KJ, Mastrandrea MD, Bilir TE, Chatterjee M, Ebi KL, Estrada YO, Genova RC, Girma B, Kissel ES, Levy AN, MacCracken S, Mastrandrea PR, White LL (eds) Cambridge University Press, Cambridge, p 1132

IPCC (2014b) Climate change 2014: synthesis report. Contribution of Working Groups I, II and III to the Fifth Assessment Report of the Intergovernmental Panel on climate change. In: Pachauri RK, Meyer LA (eds), IPCC, Geneva, p 151

IPT—Instituto de Pesquisas Tecnológicas de São Paulo (2005) Mapeamento e diagnóstico das áreas de risco associados a processos de instabilidade do terreno nas encostas dos morros de Santos, SP. Relatório Técnico 77-889205. São Paulo, Brasil. (in Portuguese)

IPT_-Instituto de Pesquisas Tecnológicas de São Paulo (2009) Plano Municipal de Habitação de Santos. Elaboração do Plano Municipal de Habitação de Santos-Contrato no 421/2008. Prefeitura Municipal de Santos. (in Portuguese)

Law 778/2012. LEI COMPLEMENTAR No 778, DE 31 DE AGOSTO DE 2012-Disciplina os procedimentos para regularização fundiária de assentamentos urbanos consolidados no município de Santos e dá outras providências. http://legislacao.camarasantos.sp.gov.br/Normas/Exibir/5207. Accessed Apr 2016

Liebmann B, Allured D (2005) Daily precipitation grids for South America. Bull Am Meteorol Soc 86:1567-1570. doi:10.1175/BAMS-87-8-1095

Liu C, Zipser EJ (2005) Global distribution of convection penetrating the tropical tropopause. J Geophys Res 110:D23. doi:10.1029/2005JD006063

Lo'aiciga HA, Pingel TJ, Garcia ES (2012) Sea water intrusion by sea-level rise: scenarios for the 21st century. Ground Water 50(1):37-47. doi:10.1111/j.1745-6584.2011.00800.x

Marengo JA, Soares WR, Saulo C, Nicolini M (2004) Climatology of the lowlevel jet east of the Andes as derived from the NCEP-NCAR reanalyses: characteristics and temporal variability. J Clim 17(12):2261-2280. doi:10.1175/1520-0442

Marengo JA, Alves LM, Soares WR, Rodrigues DA (2013a) Two contrasting severe seasonal extremes in Tropical South America in 2012: flood in Amazonia and drought in Northeast Brazil. J Clim Am Meteorol Soc 26:9137-9154. doi:10.1175/JCLI-D-12-00642.1

Marengo JA, Valverde MC, Obregon GO (2013b) Observed and projected changes in rainfall extremes in the Metropolitan Area of São Paulo. InterRes CR. 57(1):61-72. doi:10.3354/cr01160

Marengo JA, Alves LM, Espinoza JC, Ronchail J (2014) Regional climates tropical South America east of the Andes (in 'state of the climate in 2013') Bull. Am Meteorol Soc. 95:S170-S171

Master Plan (2013) Revisão do Plano Diretor de Desenvolvimento e Expansão Urbana do Município de Santos. Lei Complementar No 731, de 11 de julho de 2011. Secretaria Municipal de Desenvolvimento Urbano, $\mathrm{p}$ 86 (in Portuguese)

Mateus M, Giordano F, Marin VH, Marcovecchio J (2008) Coastal zone management in South America with a look at the three distinct estuarine systems. In: Neves R, Baretta JW, Mateus M (eds) Perspective on integrated coastal zone management in South America. IST Press, Lisboa, p 590

Mechanic D, Tanner J (2007) Vulnerable People, groups, and populations: societal view. Health Aff 26(5):1221-1230. doi:10.1377/hlthaff.26.5.1220 
Meyssignac B, Cazenave A (2012) Sea level: a review of present-day and recent-past changes and variability. J Geodyn 58:96-109. doi:10.1016/j. jog.2012.03.005

Miller STK, Keim BD, Talbot RW, Mao H (2003) Sea breeze: structure, forecasting and impacts. Revs. Geophys. 41(3):1-31. doi:10.1029/2003RG000124

Miller R, Lacambra C, Ariza C, Bloch R, Papachristodoulou N, Monroy J, Zaidi Z, Pelling M, PhungT (2012) Climate change adaptation planning in Latin American and Caribbean Cities. A report submitted by ICF GHK in association with King's College London and Grupo Laera, p 112

Morchain D (2012) Introduction: framework for local responses to climate change: challenges and recommendations resilient cities 2 Series local sustainability. Springer, Berlin, pp 221-224

Muehe D (2010) Brazilian coastal vulnerability to climate change. Pan-Am J Aquat Sci 5(2):173-183

Nicholls RJ, Wong PP, Burkett VR, Codignotto JO, Hay JE, McLean RF, Ragoonaden S, Woodroffe CD (2007) In: Change ML, Parry OF, Canziani JP, Palutikof PJ, Linden V, Hanson CE (eds) Coastal systems and low-lying areas Climate Change 2007 impacts, adaptation and vulnerability Contribution of Working Group II to the Fourth Assessment Report of the Intergovernmental Panel on Climate. Cambridge University Press, Cambridge, pp $315-356$

Nobre P (2011) A variabilidade interannual do Atlântico Tropical e sua influência no clima da América do Sul. http://www.climanalise.cptec.inpe. br/ rclimanl/boletim/cliesp10a/clmse_pn.html

Nobre P, Marengo JA, Cavalcanti IFA, Obregon G, Barros V, Camilloni I, Campos N, Ferreira AG (2006) Seasonal to-decadal predictability and prediction of South American climate. J. Clim 19:5988-6004. doi:10.1175/JCLI3946.1

Nobre P, Almeida RA, Malagutti M, Giarolla E (2012) Coupled ocean-atmosphere variations over the South Atlantic Ocean. J Clim 25:6349-6358. doi:10.1175/JCLI-D-11-00444.1

Pelling M (2011) Adaptation to climate change: from resilience to transformation, Routlege, p 203

Pezzoli A, Alfredini P, Arasaki E, Rosso M, Sousa WC (2013a) Impacts of climate changes on management policy of the harbors, land areas and wetlands in São Paulo State Coastline (Brazil). J Climatol Weather Forecast 1:101. doi:10.4172/2332-2594.1000101

Pezzoli A, Cartacho DL, Arasaki E, Alfredini P, de Oliveira Sakai R (2013b) Extreme events assessment methodology coupling rainfall and tidal levels in the coastal flood plain of the São Paulo North Coast (Brazil) for engineering projects purposes. J Climatol Weather Forecast 1(1):103. doi:10.4172/2332-2594.1000103

Prasetya G (2007) Protection from Coastal Erosion. Thematic paper: the role of coastal forests and trees in protecting against coastal erosion. FAO-UNFood and Agriculture Organization of the United Nations

Pupo F (2011) Ressaca provoca estragos e prejuízos em três cidades da Baixada Santista. http://noticias.uol.com.br/cotidiano/ultimas-noticias/2011/05/04/ressaca-provocaestragos-e-prejuizos-em-tres-cidadesda-baixada-santista.htm. Accessed Apr 2016

Rahmstorf S, Cazenave A, Church JA, Hansen JE, Keeling RF, Parker DE, Somerville RCJ (2007) Recent climate observations compared to projections. Science 316:709. doi:10.1126/science.1136843

Rahmstorf S, Perrette M, Vermeer M (2012a) Testing the robustness of semiempirical sea level projections. Clim Dyn 39:861-875. doi:10.1007/ s00382-011-1226-7
Rahmstorf S, Foster G, Cazenave A (2012b) Comparing climate projections to observations up to 2011. Environ Res Lett 7:044035. doi:10.1088/1748-9326/7/4/044035

Sampaio AFP, Ferreira JMS (2008) Socio-economic issues in Santos estuary. In Neves R, Baretta JW, Mateus M (eds) Perspectives on Integrated Coastal Zone Management in South America. IST Press, Lisboa, p 590

Santos AD (2014) Revitalization to whom? Urban policy and gentrification in Downtown Santos. Revitalização para quem? Política urbana e gentrificação no Centro de Santos. Cad. Metrópole, São Paulo 16(32): 587-607 (in Portuguese)

SEADE (2010) Índice Paulista de Vulnerabilidade Social IPVS. http://indices-ilp. al.sp.gov.br/view/pdf/ipvs/mun3548500.pdf. Accessed Apr 2016

SEADE (2011) São Paulo Demográfico. Resenha de Estatísticas Vitais do Estado de São Paulo. Ano 11. No 3. Edição revista em outubro de 2011 , em função da disponibilização dos resultados preliminares do universo do Censo Demográfico 2010, pelo IBGE, em abril de 2011, p 11 (in Portuguese)

SEADE (2013-2015) Anuário Estatístico do Estado de São Paulo http://www. imp.seade.gov.br/frontend/\#/perfil. Accessed Apr 2016

Siqueira JR, Machado LT (2003) Influence of the frontal systems on the dayto-day convection variability over South America. J Clim 17:1754-1766. doi:10.1175/1520-0442

Swyngedouw E, Heynen NC (2003) Urban political ecology, justice and the politics of scale Special issue Antipode Editorial Board of Antipode. Blackwell Publishing, Hoboken, pp 898-918. doi:10.1111/j.1467-8330.2003.00364.x

UNFPA (2015) - The United Nations Population Fund. State of world population 2015. http://www.unfpa.org/sites/default/files/sowp/downloads/ State of World Population_2015 EN.pdf. Accessed Apr 2016

USGS (2016) United States Geological Survey Aquifers and Groundwater. http://water.usgs.gov/edu/earthgwaquifer.html Accessed Apr 2016

Villanueva SP (2011) Learning to ADAPT: monitoring and evaluation approaches in climate change adaptation and disaster risk reduction-challenges, gaps and ways forward. The climate smart disaster risk management approach. Strength Clim Resil: 49

Wang C, Xie SP, Carton JA (2004) Tropical Atlantic variability: patterns, mechanisms, and impacts. In: Wang C, Xie SP, A Carton (eds) Earth's climate: the ocean-atmosphere interaction doi:10.1029/147GM07

Wisner B, Blaikie P, Cannon T, Davis I (2004) At Risk: natural hazards, people's vulnerability and disasters. Routledge, New York

Young AF (2010) Mudanças Climáticas: entre a coesão e a fragmentação dos assentamentos humanos, os conflitos e as transformações da paisagem na Baixada Santista. In: População e Mudanças Climáticas: Dimensões Humanas das Mudanças Climáticas Globais. Org. Daniel Joseph Hogan and Eduardo Marandola Junior. UNFPA. (in Portuguese).p 223-247

Young AF (2013) Urbanization, environmental justice, and social-environmental vulnerability in Brazil. In: Boone G, Fragkias M (eds) Urbanization and sustainability: linking urban ecology, environmental justice and global environmental change, human-environment interactions. Springer, Berlin, pp 95-116

Young AF (2016) Extreme events and their impacts on urban areas. In: Seto C, Solecki D, Griffth A (eds) The Routledge handbook of urbanization and global environmental change. Routledge Handbooks, Routledge, pp 229-246 